\title{
Glucose Modulation of Amino Acid-Induced Glucagon and Insulin Release in the Isolated Perfused Rat Pancreas
}

\author{
Anthony S. Pagliara, Susan N. Stillings, Barbara Hover, Duane M. Martin, and \\ Franz M. MatschinsKY \\ From the Edward Mallinckrodt Departments of Pharmacology and Pediatrics, \\ Washington University School of Medicine, St. Louis, Missouri 63110
}

A в S T RAC T Interactions between glucose and arginine and a mixture of 20 amino acids found in normal rat serum were studied in the isolated perfused rat pancreas of normal rats, with release of immunoreactive glucagon and insulin as parameters. Secretion of both pancreatic hormones was low during the steady state, whether glucose $(5 \mathrm{mM})$ was included in the perfusion medium or not. This glucose concentration significantly stimulated insulin release twofold and resulted in an $80 \%$ inhibition of basal glucagon release. Arginine and the amino acid mixture were potent stimulants of both hormones. Secretion of both hormones followed identical biphasic response patterns after addition of arginine or the amino acid mixture. However, stimulation of insulin release occurred only when glucose was included, whereas both phases of glucagon release were elicited in the absence of glucose and markedly reduced in its presence. The dose-dependency curves of hormone release due to arginine on one hand and the amino acid mixture on the other differed substantially: with arginine, release of insulin and glucagon was linear between a concentration of 0.3 and $20 \mathrm{mM}$. In contrast, the amino acid mixture resulted in half-maximal release for both hormones between a concentration of 3 and $4.5 \mathrm{mM}$, and maximal release between 6 and $8 \mathrm{mM}$. The dose-dependencies of glucose modulation of $\alpha$ - and $\beta$-cell activity were also different: when the amino acid mixture was maintained at $15 \mathrm{mM}$ and glucose varied $(0-6.25 \mathrm{mM})$, no insulin release occurred until glucose was above $2.5 \mathrm{mM}$, whereas incremental inhibition of glucagon occurred through the complete dose range. It was also observed that glucose inhibition of amino acid-stimulated glucagon re-

This work was presented in part at the meeting of the Endocrine Society, Chicago, I11., June 22, 1973.

Dr. Pagliara is an investigator of the Howard Hughes Medical Institute.

Received for publication 21. March 1974 and in revised form 31 May 1974. lease was dissociated from glucose-dependent increase of insulin release.

These studies indicate that: (a) the $\alpha$-cell, like the $\beta$-cell, secretes at a low basal rate; $(b)$ hypoglycemia per se is a weak stimulus for glucagon secretion compared to the high efficacy of a physiologic amino acid mixture; (c) glucose plays opposite roles in the mechanisms leading to amino acid-induced hormone release from the $\alpha$ - and $\beta$-cells, functioning as an inhibitor in the first case and a permissive agent in the second, and (d) the data are compatible with the postulated existence of glucose and amino acid receptors in both the $\alpha$ - and $\beta$-cells.

\section{INTRODUCTION}

Glucagon and insulin are considered to be important hormones for the maintenance of minute-to-minute fuel homeostasis of the organism (1). The $\alpha$ - and $\beta$-cells, the source of these hormones, are chemoreceptor cells with a broad spectrum capable of rapid response to almost any alteration in the body's supply of assorted nutrients. Since the actions of insulin and glucagon on peripheral tissues in regard to carbohydrate, protein, and fat metabolism are clearly antagonistic, it is not surprising that the mechanisms responsible for the secretion of these two hormones are likewise regulated in opposite ways; in general terms, conditions which stimulate $\alpha$-cells usually inhibit $\beta$-cells and vice versa. Both glucose and fatty acids, for example, cause insulin release, whereas glucagon release appears to be inhibited by these substances (2-4). Amino acids, however, seem to present an exception to this general rule, since they lead to hormone release from both $\alpha$ - and $\beta$-cells (1, $5-7)$. In spite of this overall understanding of $\alpha$ - and $\beta$-cell physiology, there is little detailed knowledge about possible complex interactions of the major small calorigenic molecules (i.e. amino acids, fatty acids,

The Journal of Clinical Investigation Volume 54 October 1974·819-832 

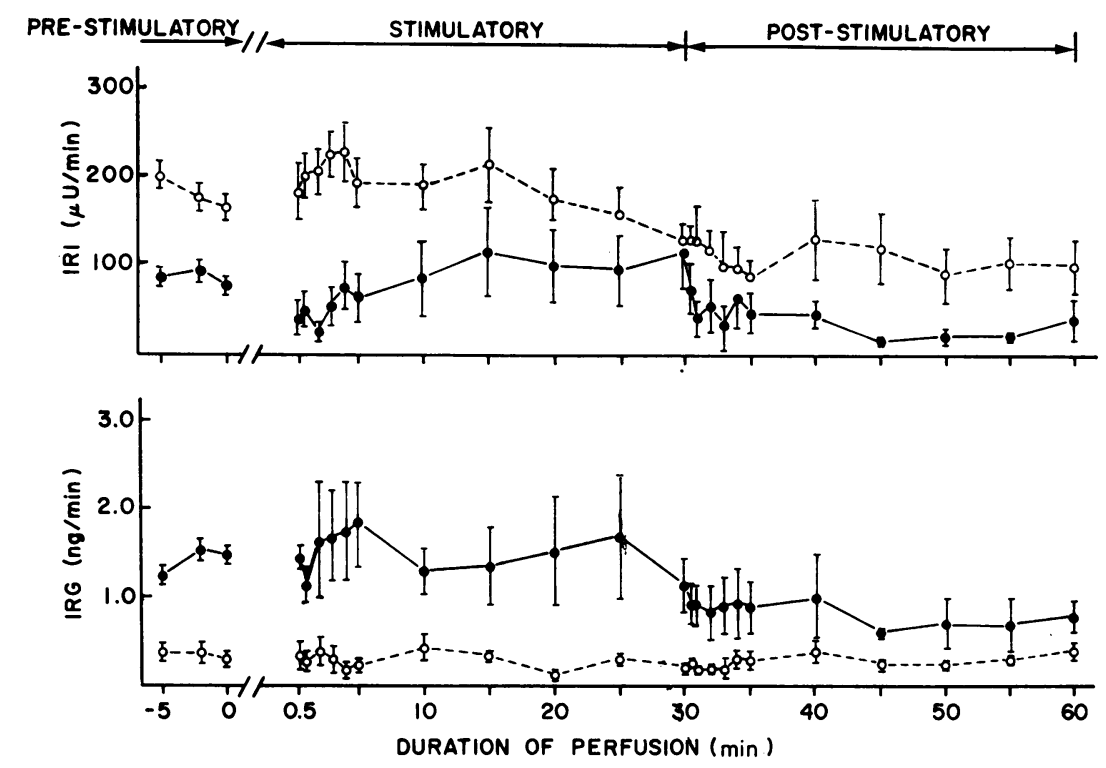

FIGURE 1 Basal insulin and glucagon release from the pancreas perfused with and without glucose. The pancreas was perfused for $75 \mathrm{~min}$ without changing the composition of the perfusate but the reservoir was switched at 0 and $30 \mathrm{~min}$ as in perfusions with the amino acid stimulants. After 10 min preperfusion, three samples were taken ( $t_{-5}, t_{-2}$, and $\left.t_{0}\right)$. The data recorded in the preperfusion period represents the mean $\pm S E M$ of all experiments performed in this study and also of those obtained in a parallel study * (insulin release without glucose, $n=84$; insulin release $+5 \mathrm{mM}$ glucose, $n=76$; glucagon release without glucose, $n=95$ and glucagon release $+5 \mathrm{mM}$ glucose, $n=76$ ). The values given during the time periods $t_{0.5}-t_{30}$ and $t_{30.5}-t_{60}$ are the means \pm SEM of the rates of release of both hormones and correspond to the stimulatory and poststimulatory time periods in perfusions performed with amino acids (insulin release without glucose, $n=8$; insulin release $+5 \mathrm{mM}$ glucose, $n=6$; glucagon release without glucose, $n=3$; and glucagon release with $5 \mathrm{mM}$ glucose, $n=3$ ). See also Table I.

- Insulin and glucagon release without glucose; ---, insulin and glucagon release with $5 \mathrm{mM}$ glucose; IRI, immunoreactive insulin; IRG, immunoreactive glucagon.

ketone bodies, and sugars) at the cellular or biochemical level.

It seems particularly important to comprehend the multiple functions that the glucose molecule might serve in regulating the chemosensitivity of the $\alpha$ - and $\beta$-cells, since it has become increasingly clear that glucose modulates the responsiveness of these cells to other stimuli, in addition to its well-known direct insulin-releasing action from $\beta$-cells. The multiple actions of glucose on islet cells have been explained in various ways. The frequently quoted unifying concept proposed by Edwards and Taylor (2) attributes glucose stimulation of $\beta$-cells on one hand and glucose inhibition of $\alpha$-cells on the other to increased provision of fuel or of critical metabolites and cofactors, i.e. insulin release occurs when the $\beta$-cells are supplied with energy and an optimal metabolite and cofactor constellation, whereas glucagon release ensues when the energy level (i.e. ATP and $P$-creatinine) is lower in $\alpha$-cells. This general notion has been extended by Unger and Lefebvre and collaborators $(1,5,8)$, who believe that in the $\alpha$-cells the provision of metabolic energy from glucose, and consequently the inhibitory action of glucose, are insulin-dependent.

Another widely accepted view holds that the two types of islet cells are fundamentally different physiologically: $\alpha$-cells are considered as inherently active cells, i.e. as pacemaker cells normally curbed by glucose levels in the physiological range, whereas $\beta$-cells require external stimuli to become activated (1). To submit these various concepts to further experimental testing, the present physiological and pharmacological studies were initiated with the isolated perfused rat pancreas. This paper is the first report of this series of studies. The major objective was to assess the possible role of glucose in regulating the function of $\alpha$ - and $\beta$-cells when stimulated by arginine or a mixture of 20 natural amino acids and to elucidate the kinetics of glucagon and insulin release in the isolated perfused rat pancreas to these stimuli as an initial step before correlation of hormonal release with possible biochemical changes occurring within the $\alpha$ and $\beta$-cell. 
TABLE I

Mean .1ierage Basal Insulin and Glucagon Release in the Presence and Absence of Glucose*

\begin{tabular}{|c|c|c|c|c|c|c|c|c|c|}
\hline Condition & $\begin{array}{l}\text { No. of } \\
\text { perfusions }\end{array}$ & $n$ & $\begin{array}{l}\mathrm{t}_{-5}-\mathrm{t}_{\mathrm{v}} \\
\text { insulin }\end{array}$ & $\begin{array}{l}\text { No. of } \\
\text { perfusions }\end{array}$ & $n$ & $\begin{array}{l}t_{0.5}-t_{30} \\
\text { insulin }\end{array}$ & $\begin{array}{l}\text { No. of } \\
\text { perfusions }\end{array}$ & $n$ & $\begin{array}{l}\mathrm{t}_{30.5}-\mathrm{t}_{611} \\
\text { insulin }\end{array}$ \\
\hline & & & $\mu U / \min$ & & & $\mu L^{\prime} / \min$ & & & $\mu U / \min$ \\
\hline -Glucose & 84 & 252 & $81 \pm 3$ & 8 & 88 & $74 \pm 10$ & 8 & 88 & $42 \pm 5 \S$ \\
\hline \multirow{3}{*}{$\begin{array}{c}+ \text { Glucose } \\
\ddagger P \\
\ddagger P\end{array}$} & 76 & 228 & $179 \pm 11$ & 6 & 66 & $19.3 \pm 9$ & 6 & 66 & $110 \pm 5 \S$ \\
\hline & & & $<0.001$ & & & $<0.001$ & & & $<0.001$ \\
\hline & & & $\begin{array}{l}\text { Glucagon, } \\
n g / \text { min }\end{array}$ & & & $\begin{array}{l}\text { Glucagon, } \\
n g / m i n\end{array}$ & & & $\begin{array}{l}\text { Glucagon, } \\
n g / m i n\end{array}$ \\
\hline -Glucose & 95 & 285 & $1.42 \pm 0.10$ & 3 & 33 & $1.51 \pm 0.07$ & 3 & 33 & $0.84 \pm 0.04 \S$ \\
\hline +Glucose $(5 \mathrm{mM})$ & 76 & 228 & $0.37 \pm 0.01$ & 3 & 33 & $0.31 \pm 0.03$ & 3 & 33 & $0.29 \pm 0.02 \|$ \\
\hline$\ddagger P$ & & & $<0.001$ & & & $<0.001$ & & & $<0.001$ \\
\hline
\end{tabular}

* The average rates of insulin and glucagon release were calculated from the data shown in Fig. 1. The values given during the time period $t_{-5}-t_{0}$ are the mean $\pm S E$.II of the rates of release at time points $t_{-5}, t_{-2}$, and $t_{0}$ for both hormones. The values given during the time periods $t_{0.5}-t_{30}$ and $t_{30.5}-t_{60}$ are the mean $\pm S E M$ of the average rates of release of both hormones when perfusions were performed with and without $5 \mathrm{mM}$ glucose (see legend to Fig. 1).

$\ddagger$ Degree of significance between perfusions with and without glucose.

$\S$ Significantly different, $P<0.001$ from $t_{-5}-t_{0}$ and $t_{0.5}-t_{30}$.

|| Significantly different, $P<0.01$ from $t_{-5}-t_{0}$.

\section{METHODS}

Animals and porfusion systom. Male Sprague-Dawley rats weighing $300-400 \mathrm{~g}$, fed ad libitum with Purina rat chow (Ralston Purina Co., St. Louis, Mo.) and water were used in all experiments. The animals were purchased from Holtzman Co., (Madison, Wisc.) or Zivic-Miller (Allison, Pa.).

The pancreas was isolated and perfused by the procedure described by Grodsky et al. (9) with minor modifications (10). After an overnight fast, the animals were atropinized $(0.1 \mathrm{mg} / \mathrm{kg}$ i.p.) and anesthetized with pentobarbital (45 $\mathrm{mg} / \mathrm{kg}$ i.p.). Atropine was given since it prevented respiratory problems that occasionally arose during the surgical procedure. The pancreas was isolated en bloc with the spleen, stomach, and proximal portion of the duodenum. Polyethylene cannulae were inserted into the celiac artery and portal vein, and the organ complex was placed in an incubator and perfused at a constant $35^{\circ} \mathrm{C}$ without recycling the medium. The flow rate was frequently measured and was maintained constant between 5 and $6 \mathrm{ml} / \mathrm{min}$. The perfusate contained routinely the following components: $\mathrm{NaCl}, 120 \mathrm{mM} ; \mathrm{KCl}, 4.7 \mathrm{mM} ; \mathrm{MgSO}_{4}, 0.8 \mathrm{mM}$; $\mathrm{CaCl}_{2}$, $2.5 \mathrm{mM}$; $\mathrm{KH}_{2} \mathrm{PO}_{4}, 1.2 \mathrm{mM}$; $\mathrm{NaHCO}_{3}, 25 \mathrm{mM}$; and dex$\operatorname{tran} 7-8 \%$. Other additions were made as described in the text below or in the legends of the appropriate figures and tables. Before perfusion, the medium was warmed to $35^{\circ} \mathrm{C}$ and gassed with a mixture of $\mathrm{O}_{2}$ and $\mathrm{CO}_{2}(95: 5)$. The resulting $\mathrm{pH}$ was 7.4.

Perfusion with amino acids in the presence and absence of basal glucose. For each experimental condition, at least six separate perfusions were performed, half of which had $5 \mathrm{mM}$ glucose present throughout. This concentration of glucose was selected since it has minor effects on basal insulin release $(11,12)$. In all experiments in which glucose and/or amino acids were studied, the pancreas was perfused for $15 \mathrm{~min}$ before exposure to the amino acid stimulant. The period of stimulation lasted $30 \mathrm{~min}$ and was followed by another control period of $30 \mathrm{~min}$ by perfusion in the absence of the amino $\operatorname{acid}(\mathrm{s})$. The transitions be- tween different conditions by switching from one circulation medium to the other were rapid and did not result in detectable changes of flow rate.

Dose-response curves for insulin and glucagon release were obtained with $\mathrm{L}$-arginine- $\mathrm{HCl}$ in concentrations of $0.3,1,5,10$, and $20 \mathrm{mM}$ and with a mixture of 20 amino acids in proportions found in normal rat serum (13), at levels of $1,3,6,10$, and $15 \mathrm{mM}$. The amino acid mixture was conveniently added as a $154.7 \mathrm{mM}$ stock solution stored at $-20^{\circ} \mathrm{C}$. The composition of this stock solution was as follows (all concentrations recorded in millimoles): alanine, $18.76(12.10 \%)$; arginine $\mathrm{HCl}, 8.03(5.20 \%)$; aspartic acid, $1.74(1.10 \%)$; citrulline, 3.99 (2.58\%); glutamic acid, $5.18(3.36 \%)$; glycine, $12.75(8.27 \%)$; histidine, $3.35(2.17 \%)$; isoleucine, $4.04(2.62 \%)$; leucine 6.97 $(4.52 \%)$; lysine $\mathrm{HCl}, 15.87$ (10.3\%); methionine, 2.06 $(1.34 \%)$; ornithine $\mathrm{HCl}, 2.98(1.93 \%)$; phenylalanine, 3.49 $(2.26 \%)$; proline, 14.91 (9.20\%); serine, 24.40 (15.90\%); threonine, $11.54(6.85 \%)$; tryptophan, 3.17 (2.06\%); valine, $8.62(5.60 \%)$. Cystine and tyrosine were separately added to the perfusion medium in solid forms because of solubility problems. The relative concentrations of these two amino acids were always 1.9 and $2.2 \%$, respectively.

In the above experiments, $0.5-\mathrm{ml}$ samples were obtained at suitable intervals from the cannula in the portal vein, briefly cooled on ice, and frozen for storage at $-20^{\circ} \mathrm{C}$ until assayed. 25 samples were taken in each experiment; of these 3 were during the preperfusion period of $15 \mathrm{~min}$ (at $t_{-\overline{-}}, t_{-2}$, and $t_{0}$ ) to obtain the basal insulin and glucagon release levels; after the switch to the medium containing the stimulant under study, samples were collected $0.5 \mathrm{~min}$ after the change, then every minute for $5 \mathrm{~min}$, and finally every $5 \mathrm{~min}$ for the remaining $25 \mathrm{~min}$ of stimulation. The same schedule of sampling was applied when the circulation was switched back to the control solution to study the poststimulatory activity. The rates of insulin and glucagon release were calculated by multiplying the concentration of the respective sample by the flow rate, which was measured at frequent intervals. Total release during $30 \mathrm{~min}$ of 


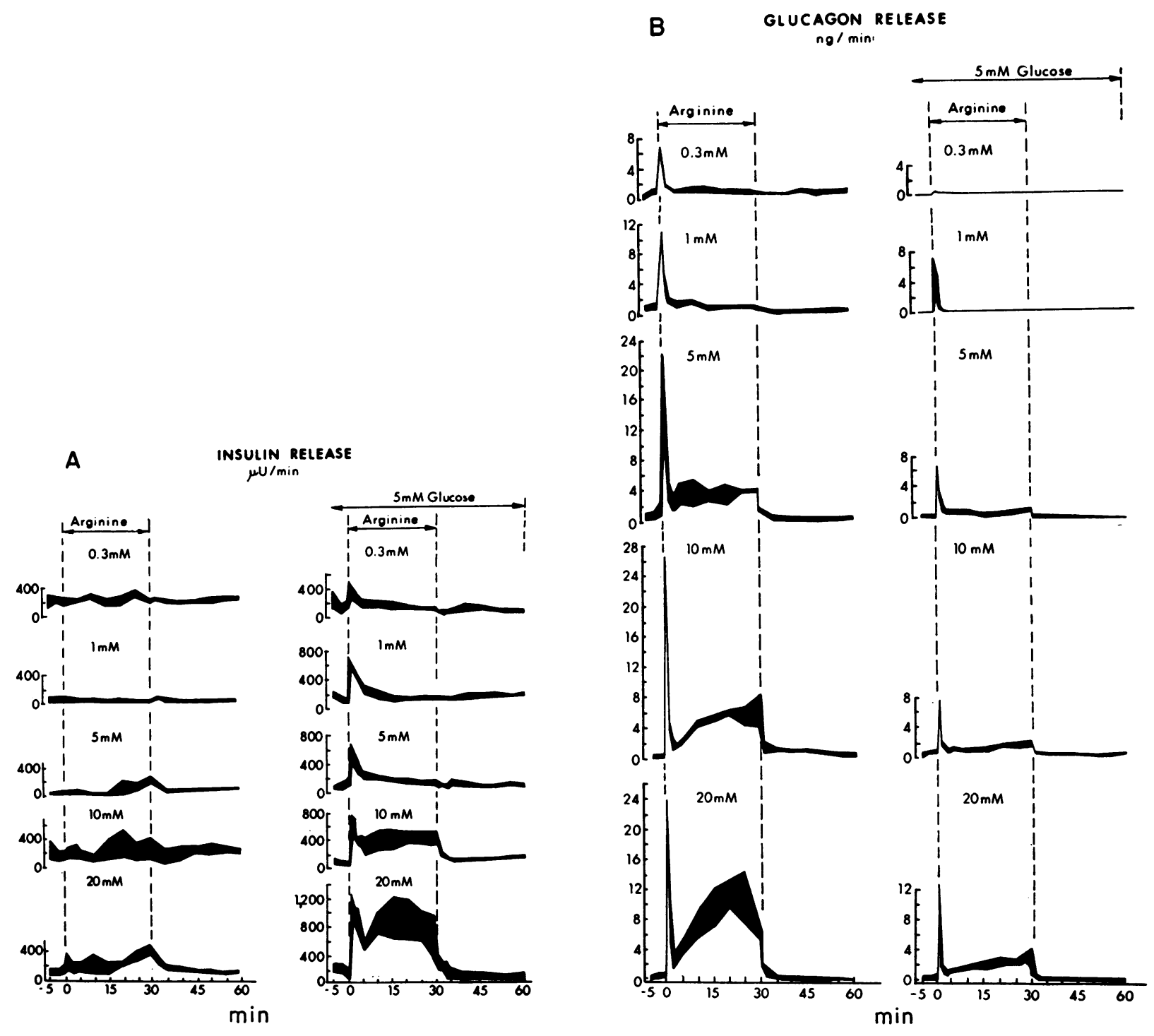

Figure 2 Glucose modulation of the $\alpha$ - and $\beta$-cell responses due to arginine and an amino acid mixture. The pancreas was perfused for $75 \mathrm{~min}$. After preperfusion for $15 \mathrm{~min}\left(t_{15}-t_{0}\right)$ the circulation was switched to a solution containing the stimulus in concentrations as indicated $\left(t_{0}-t_{30}\right)$. The poststimulatory responsiveness was tested by switching back to the preperfusion fluid $\left(t_{30}-t_{00}\right)$. In each panel are shown the data obtained with and without basal

exposure to a stimulus was obtained by planimetry of the means of the profiles of usually three perfusions. The net release during the period of stimulation was calculated by deducting the average secretion observed during the preperfusion period. This seemed justified since the fluctuations of the very low basal secretion rate for both hormones were small relative to the magnitudes of responses seen in the presence of effective stimuli.

Iminunoassay procedures. Insulin was measured in duplicate by the double-antibody procedure of Hales and Randle (14), with porcine insulin as standard. To the buffer in the standard curves, Krebs-Henseleit-dextran was added in the same concentration as in the sample tubes.
Glucagon was measured also in duplicate by a doubleantibody procedure with a guinea pig antiglucagon antibody developed in our laboratory. This antibody has slight crossreactivity with gut glucagon, but it gives comparable values for serum to those obtained with Unger's antibody $30 \mathrm{~K}$. Porcine glucagon was used as a standard. [ $\left.{ }^{150} \mathrm{I}\right]$ porcine glucagon $(500-600 \mu \mathrm{Ci} / \mu \mathrm{g})$ was prepared by a slight modification of the method of Hunter and Greenwood (15). In the assay, $100 \mu \mathrm{l}$ of sample or standard was preincubated with $400 \mu 1$ of buffer containing $0.2 \mathrm{M}$ glycine, $\mathrm{pH} 8.8,1 \%$ bovine serum albumin (Sigma Chemical Co., St. Louis,

${ }^{1}$ Manuscript submitted for publication. 


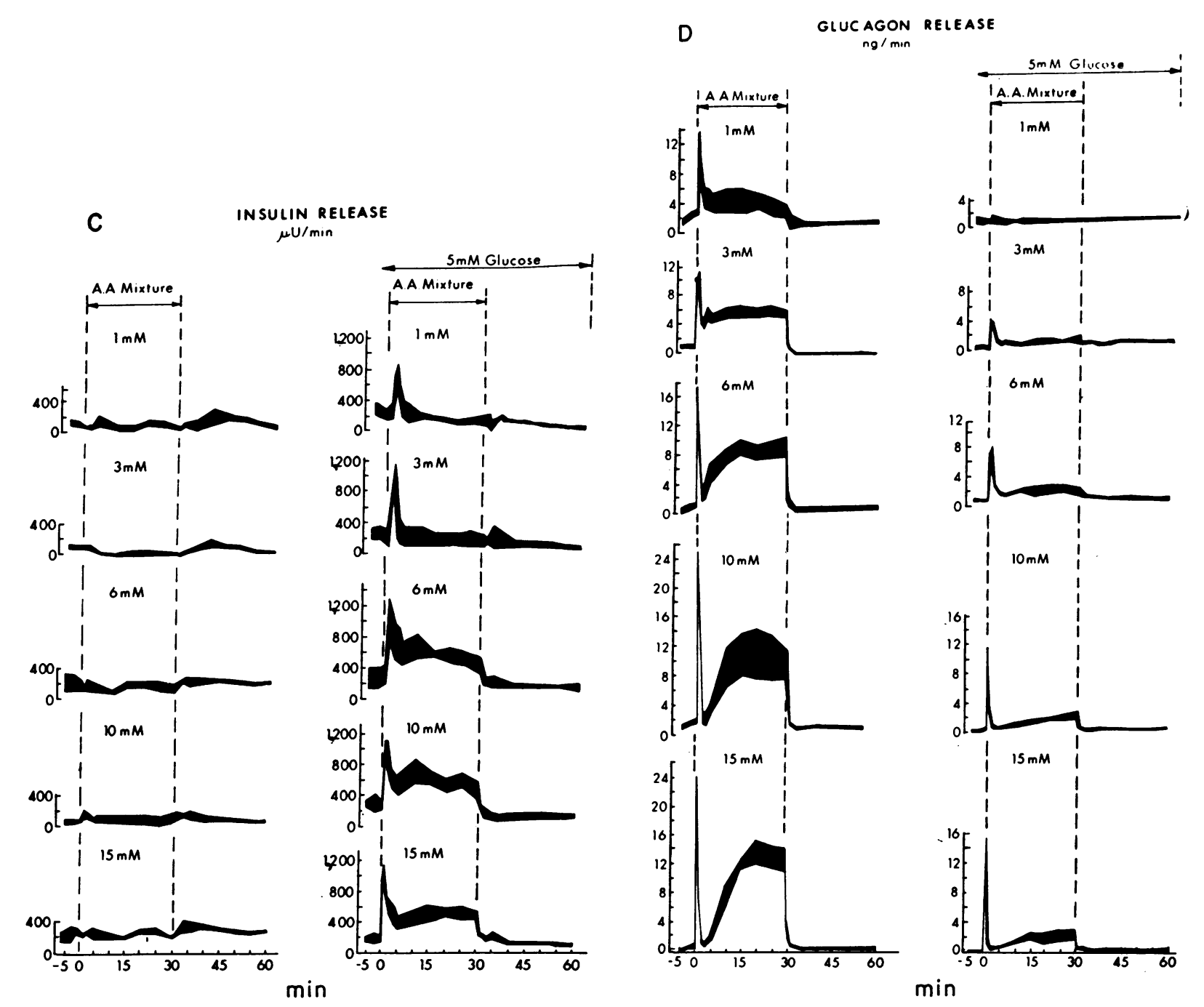

glucose, which was present throughout the entire $75 \mathrm{~min}$. A and B: insulin and glucagon release profiles due to arginine; $\mathrm{C}$ and $\mathrm{D}$ : insulin and glucagon release profiles due to the amino acid mixture (see Method section concerning the composition of the mixture). For each condition, three experiments are recorded. The widths of the bands represent two SEM's.

Mo., fraction V) and 1,000 kallikrein inactivator units Trasylol/ml (FBA Pharmaceuticals, New York). The final antibody dilution during this step was $1: 32,000$. In the standard curves Krebs-Henseleit-Dextran was added in the same concentrations as in the sample tube. The tubes were incubated for 4 days at $4^{\circ} \mathrm{C}$; the preincubation extended over $24 \mathrm{~h}$ and the incubation with ${ }^{125} \mathrm{I}$ lasted for $72 \mathrm{~h}$. Separation of bound from free glucagon was accomplished by precipitation of the bound with goat antiguinea pig gamma globulin and normal guinea pig serum. The lower limit of detection of the assay system is $5.0 \mathrm{pg}$. The standard deviation of the intrassay variability is $8 \%$ and that of the interassay variability $12 \%$.

All substances added to the perfusion medium were tested at the highest concentration used for possible interference in the immunoassays.

\section{RESULTS}

Basal glucagon and insulin release. Secretion of both pancreatic hormones was low during the steady state, whether basal glucose $(5 \mathrm{mM})$ was included in the perfusion medium or not (Fig. 1, Table I). This basal release varied substantially both among individual experiments and during the course of a single perfusion. However, the fluctuations of the base line would appear to be a minor problem, considering the high rates of release seen during amino acid stimulation.

Perfusion with $5 \mathrm{mM}$ glucose doubled insulin release during each period corresponding to the prestimulatory $\left(t_{-}-t_{0}\right)$, stimulatory $\left(t_{0.5}-t_{\infty}\right)$, and poststimulatory 
phases $\left(\mathrm{t}_{30.5}-\mathrm{t}_{80}\right)$ of perfusion when amino acids were included as stimulants (Fig. 1, Table I). The average rates of insulin release (in microunits per minute, mean $\pm \mathrm{SEM}$ ) when compared to perfusion with $5 \mathrm{mM}$ glucose were: $t_{-5}$ to to, $81 \pm 3(n=252)$ vs. $179 \pm 11(n=$ $228) ; \mathrm{t}_{0.5}$ to $\mathrm{t}_{30}, 74 \pm 10(n=88)$ vs. $193 \pm 9(n=66)$; and $t_{30.5}$ to $t_{60}, 42 \pm 5(n=88)$ vs. $110 \pm 15 \quad(n=66)$; for all values, $P<0.001$.

Within both types of perfusion (with or without glucose), the average insulin release rates corresponding to the prestimulatory and stimulatory phases were virtually identical. However, in the poststimulatory phase, the average insulin release rate for both conditions was significantly lower than the corresponding prestimulatory and stimulatory periods (Fig. 1, Table I).

Perfusion with $5 \mathrm{mM}$ glucose inhibited basal glucagon secretion. The average rates of glucagon release (in nanograms per minute, mean $\pm \mathrm{SEM}$ ) when compared to perfusions with $5 \mathrm{mM}$ glucose were: t-5 to to, $1.42 \pm 0.10(n=285)$; vs. $0.37 \pm 0.01(n=228) ;$ to. 5 to $\mathrm{t}_{30}, 1.5 \pm 0.07(n=33)$ vs. $0.31 \pm 0.03(n=33)$ and $\mathrm{t}_{30.5}$ to too, $0.84 \pm 0.04(n=33)$ vs. $0.29 \pm 0.02(n=33)$, for all values $P<0.001$. As with insulin, within both types of perfusion (with or without glucose), the average glucagon release rates corresponding to the prestimulatory and stimulatory phases did not differ. However, there was a significant decrease in the average glucagon release during the poststimulatory phase in the perfusions without glucose $(P<0.001$, Table I). Low rates of basal insulin and glucagon release were also observed in an independent study with the isolated perfused canine pancreas (6).

We felt that this data justified the subtraction of the prestimulatory ( $t-5$ to $t_{0}$ ) insulin and glucagon release rates, obtained from each individual perfusion when calculating rates of release above basal levels in the presence of an amino acid stimulus.

The effect of arginine and other individual amino acids on $\alpha$ - and $\beta$-cells. Arginine, in concentrations from 0.3 to $20 \mathrm{mM}$, had little to no effect by itself in increasing insulin secretion. It is particularly striking that in the absence of glucose the initial hormone peak is clearly absent (Fig. 2A). However, when $5 \mathrm{mM}$ glucose was included in the perfusate, graded stimulation of insulin release occurred readily with increasing concentrations of the amino acid and the biphasic pattern previously described for glucose and many other stimulants was present $(6,11,12)$. The peak of the first phase was obtained between 30 and $60 \mathrm{~s}$ after the switch with all concentrations and the nadir occurred between 3 and 5 min. A sustained second phase was observed with 10 and $20 \mathrm{mM}$ arginine. After $30 \mathrm{~min}$ of continued perfusion with both arginine and $5 \mathrm{mM}$ glucose, the switch to $5 \mathrm{mM}$ glucose alone resulted in a rapid de- crease in the secretion rate. The rate decreased with first-order kinetics, showing a half-time of approximately $10 \mathrm{~s}$. Release during the poststimulatory phase was as low as during preperfusion.

The responses of the $\alpha$-cells obtained with increasing concentrations of arginine differ dramatically from the responses of the $\beta$-cells (Fig. 2B). Glucagon release was markedly stimulated by arginine alone and was attenuated by addition of $5 \mathrm{mM}$ glucose. There were two phases, as observed for insulin. The peak response for the first phase occurred within $30 \mathrm{~s}$ and returned to almost basal secretory levels within 2-3 min. A sustained second phase of release was seen with 10 and 20 $\mathrm{mM}$ arginine. Although $5 \mathrm{mM}$ glucose inhibited glucagon release over the entire concentration range, biphasic responses were still maintained with $5-20 \mathrm{mM}$ arginine. The decay of release after removal of the stimulus both with and without glucose was as rapid as seen for the insulin response, and reached basal levels in approximately $1 \mathrm{~min}$.

In selected studies with $3 \mathrm{mM}$ asparagine or alanine, both in the presence and absence of $5 \mathrm{mM}$ glucose the $\alpha$ and $\beta$-cell responses were quantitatively and qualitatively comparable to the results seen with corresponding concentrations of arginine (data not shown).

The present results with arginine agree generally with data from other in vitro studies and particularly with the findings of Iversen, who used the isolated perfused dog pancreas (6), and with the findings of Levin, Grodsky, Hagura, Smith, and Forsham (16), who also employed the isolated perfused rat pancreas. However, in the latter study, arginine had a more pronounced effect on insulin release even in the absence of glucose, particularly at the very high levels used (16).

Studies with a mixture of 20 amino acids. Since unphysiologically high concentrations of arginine and of other individual amino acids were used in the experiments just described (10-200 times the physiological levels) the studies were repeated with a mixture of 20 natural amino acids in concentrations and proportions found in normal rat serum (13). Serum concentrations of total amino acids after an overnight fast are approximately $3 \mathrm{mM}$ (13) and are likely to increase to $4.5-6 \mathrm{mM}$ postprandially.

The insulin release profiles with the amino acid mixture were qualitatively similar to those observed with arginine (Fig. 2C). No stimulation of release occurred in the absence of glucose, even at the highest amino acid concentrations $(15 \mathrm{mM})$. With $5 \mathrm{mM}$ glucose, the amino acid mixture stimulated insulin release with a single initial peak at 1 and $3 \mathrm{mM}$ and a biphasic response at 6,10 , and $15 \mathrm{mM}$.

Secretion stopped rapidly on removal of the stimulus, as noted with arginine. Again, no poststimulatory hy- 


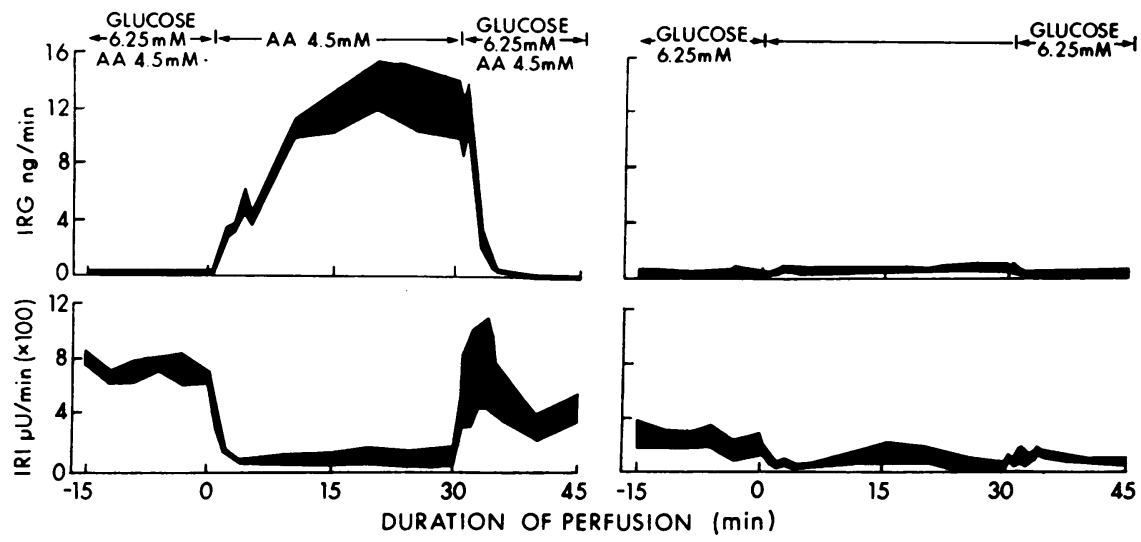

FIGURE 3 Effect of acute hypoglycemia on insulin and glucagon release with and without amino acid stimulation. The pancreas was perfused for $75 \mathrm{~min}$. The panel on the left illustrates insulin and glucagon release when the amino acid mixture is maintained throughout the entire perfusion period and glucose is added and removed as indicated. The width of the bands represent two SE $(n=4)$. The panel on the right illustrates insulin and glucagon release in the absence of an amino acid stimulus when glucose is added and removed as indicated $(n=3)$. The first point $\left(t_{-15}\right)$ is obtained 15 min after starting the perfusion.

perresponsiveness to glucose became apparent. In this regard, arginine and the amino acid mixture differ markedly from high glucose, leucine, isoleucine, ketone bodies, cetrain fatty acids, and $\alpha$-keto-monocarboxylic acids, all of which lead to poststimulatory hyperresponsiveness to basal glucose (17). The data indicate that the sensitization of the $\beta$-cells to basal glucose is not simply a consequence of sustained excitation and secretion. It is conceivable that hyperresponsiveness to glucose is induced only by those substances that enhance glucose metabolism concomitant with triggering release. Consistent with this explanation are recent findings in our laboratory that show that in isolated islets, $10 \mathrm{mM}$ L-isoleucine markedly stimulates lactate production from basal glucose, whereas the same level of arginine and of the mixture of 20 amino acids has little effect on lactate formation. ${ }^{2}$

As with arginine alone, glucagon release was markedly and progressively enhanced by increasing concentrations of the amino acid mixture; the biphasic pattern occurred with concentrations as low as $1 \mathrm{mM}$ (Fig. 2D). All secretion profiles were drastically suppressed by the presence of $5 \mathrm{mM}$ glucose.

The effect of acute hypoglycemia on $\alpha$ - and $\beta$-cells previously exposed to physiological levels of amino acids $(4.5 \mathrm{mM})$ and glucose $(6.25 \mathrm{mM})$ was tested (Fig. 3). There was a definite delay after the switch to the glucose-free solution before the glucagon response became apparent. The release profile was monophasic, lacking the pronounced initial spike seen on exposure to amino acids. In contrast to the glucagon response, the first

\footnotetext{
${ }^{2}$ Unpublished data.
}

peak was present in the insulin profile when basal glucose was reintroduced.

In the control experiments (amino acids omitted) abrupt aglycemia produced a comparatively minor glucagon response (Fig. 3 ). This experiment suggests that the tonic influence of plasma amino acids and the acute fall in blood glucose may be the primary factors responsible for the release of glucagon during hypoglycemia in vitro. The above factors together with inputs from the autonomic nervous system may in combination be responsible for glucagon release during hypoglycemia in vivo (18).

Characteristics of dose-response curves due to arginine and the amino acid mixture. The concentration dependency of glucagon and insulin release provoked by arginine and amino acids, both in the absence and presence of basal glucose, exhibits features of probable physiological significance, as illustrated in Fig. 4. The total hormone release during exposure to the stimulant is recorded, neglecting the multiphasic kinetics of release. The system, which responds to arginine plus glucose by releasing insulin, was not saturated by arginine, even at $20 \mathrm{mM}$. Unlike arginine, the amino acid mixture together with $5 \mathrm{mM}$ glucose resulted in half-maximal secretion at 4.5-5 $\mathrm{mM}$ and maximal secretion with 6-8 $\mathrm{mM}$ levels of amino acid, concentrations within the physiologic range. The steepness of the curve obtained with the mixture suggests the possibility of cooperative effects among the different amino acids. That this might be the case is also suggested by the results of corresponding in vivo studies $(7,19)$. The relative contribution of the individual amino acids to the overall response remains to be unraveled. 

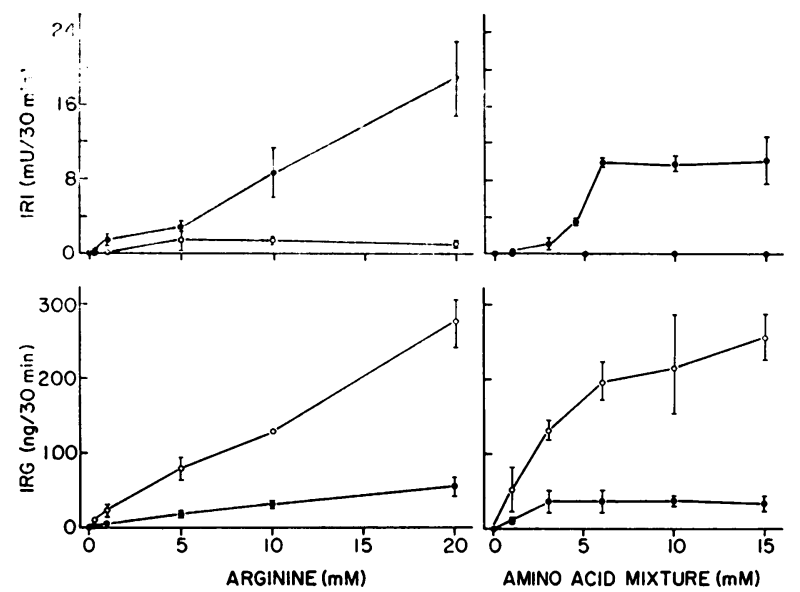

FIgURE 4 Dose and glucose dependency of insulin and glucagon release by arginine and an amino acid mixture. This is a synopsis of the data presented in Fig. 2. The mean $\pm \mathrm{SEM}$ of total hormone release during $30 \mathrm{~min}$ of exposure to the stimulus is recorded. It was obtained by planimetry of the profiles presented in Fig. 2. Correction was made for basal release in the absence of the stimulus by extrapolating from the average secretion observed in the preperfusion period. For more details see the Methods section.

Basal glucose inhibited glucagon release due to arginine and to the amino acid mixture by approximately $80 \%$ at all levels of the stimulants. As with insulin, the dose-response curves demonstrate the failure of arginine to saturate the system involved in glucagon secretion, whereas the amino acid mixture with or without glucose resulted in near-maximal stimulation within the physiologic range of amino acid concentration.

Concentration dependency of glucose actions allowing $\alpha$-cell stimulation and leading to $\beta$-cell inhibition. In all studies described above, a constant level of $5 \mathrm{mM}$ glucose was employed. The permissive and inhibitory action $^{3}$ of glucose on $\beta$-cells and $\alpha$-cells, respectively, was further investigated by maintaining the amino acid mixture at a level of $15 \mathrm{mM}$ and perfusing with increasing concentrations of glucose $(0-6.25 \mathrm{mM}$ ) (Fig. 5, Tables II and III).

The permissive action of glucose in allowing insulin release by amino acids revealed a clear threshold of the effect at $2.5 \mathrm{mM}$ glucose; no insulin release occurred below this concentration (Fig. 5, Table II). In contrast, the inhibition of $\alpha$-cell activity became manifest at the lowest glucose levels used $(1.25 \mathrm{mM})$ and further increased up to $6.25 \mathrm{mM}$, at which point glucagon secretion was $6-7 \%$ of the secretion rate of the perfusions without glucose (Fig. 5, Tables II and III).

Both the permissive and the inhibitory actions of glucose on $\beta$ - and $\alpha$-cells, respectively, manifest themselves

${ }^{3}$ The terms "permissive and inhibitory actions of glucose" seem reasonable in a physiologic sense but are not meant to imply any knowledge about the molecular mechanisms underlying the phenomena described by them.

TABLE II

Dose-Dependency of Glucose Action on the Two Phases of Insulin and Glucagon Release Caused by 15 mM Amino Acid Mixture

\begin{tabular}{|c|c|c|c|c|c|c|}
\hline \multirow[b]{2}{*}{ Glucose } & \multicolumn{3}{|c|}{ Insulin* } & \multicolumn{3}{|c|}{ Glucagon* } \\
\hline & $\begin{array}{c}\text { 1st phase } \\
0-3 \mathrm{~min}\end{array}$ & $\begin{array}{l}\text { 2nd phase } \\
3-30 \mathrm{~min}\end{array}$ & $\begin{array}{c}\text { Total } \\
0-30 \mathrm{~min}\end{array}$ & $\begin{array}{c}\text { 1st phase } \\
0-3 \text { min }\end{array}$ & $\begin{array}{l}\text { 2nd phase } \\
\text { 3-30 min }\end{array}$ & $\begin{array}{c}\text { Total } \\
0-30 \mathrm{~min}\end{array}$ \\
\hline$m M$ & $m U / 3 \min$ & $m U / 27$ min & $m U / 30 \mathrm{~min}$ & $n g / 3 \min$ & $n g / 27 \min$ & $n g / 30$ min \\
\hline 0 & 0 & 0 & 0 & $\begin{array}{r}17.20 \\
\pm 1.40\end{array}$ & $\begin{array}{r}247.00 \\
\pm 31.00\end{array}$ & $\begin{array}{r}264.20 \\
\pm 31.00\end{array}$ \\
\hline 1.25 & 0 & $\begin{array}{r}0.06 \\
\pm 0.06\end{array}$ & $\begin{array}{r}0.06 \\
\pm 0.06\end{array}$ & $\begin{aligned} & 6.90 \ddagger \\
\pm & 0.88\end{aligned}$ & $\begin{array}{r}203.00 \\
\pm 53.00\end{array}$ & $\begin{array}{r}209.90 \\
\pm 53.00\end{array}$ \\
\hline 2.50 & $\begin{aligned} & 0.72 \ddagger \\
\pm & 0.14\end{aligned}$ & $\begin{array}{r}0.34 \\
\pm 0.31\end{array}$ & $\begin{array}{l}1.06 \ddagger \\
\pm 0.45\end{array}$ & $\begin{array}{l}4.23 \ddagger \\
\pm 0.38\end{array}$ & $\begin{array}{c}150.00 \ddagger \\
\pm 42.00\end{array}$ & $\begin{array}{l}154.23 \ddagger \\
\pm 42.00\end{array}$ \\
\hline 3.75 & $\begin{aligned} & 2.20 \ddagger \\
\pm & 0.37\end{aligned}$ & $\begin{aligned} & 6.52 \ddagger \\
\pm & 0.95\end{aligned}$ & $\begin{aligned} & 8.75 \ddagger \\
\pm & 1.21\end{aligned}$ & $\begin{aligned} & 4.60 \ddagger \\
\pm & 0.34\end{aligned}$ & $\begin{array}{r}35.60 \ddagger \\
\pm 17.30\end{array}$ & $\begin{aligned} & 40.20 \ddagger \\
\pm & 17.60\end{aligned}$ \\
\hline 5.00 & $\begin{array}{r}1.83 \ddagger \\
\pm 0.36\end{array}$ & $\begin{aligned} & 8.20 \ddagger \\
\pm & 1.22\end{aligned}$ & $\begin{array}{l}10.03 \ddagger \\
\pm 1.55\end{array}$ & $\begin{array}{r}5.40 \\
\pm 0.60\end{array}$ & $\begin{array}{r}29.60 \ddagger \\
\pm 10.00\end{array}$ & $\begin{aligned} & 35.00 \ddagger \\
\pm & 10.50\end{aligned}$ \\
\hline 6.25 & $\begin{aligned} & 2.69 \ddagger \\
\pm & 0.53\end{aligned}$ & $\begin{array}{l}20.22 \ddagger \\
\pm 3.48\end{array}$ & $\begin{array}{l}22.91 \ddagger \\
\pm 4.00\end{array}$ & $\begin{aligned} & 4.54 \ddagger \\
\pm & 0.77\end{aligned}$ & $\begin{array}{l}13.00 \ddagger \\
\pm 4.35\end{array}$ & $\begin{array}{c}17.54 \ddagger \\
\pm 4.10\end{array}$ \\
\hline
\end{tabular}

* The values represent the mean $\pm \mathrm{SEM}$ of the integrated secretion rates of insulin and glucagon above base line as obtained by planimetry of the areas under the curves extending over the indicated time periods ( $n=3$ for each condition).

‡ Significantly different from control rates obtained in the absence of glucose $(P \leqq 0.02)$. 
more readily in the first peaks than in the sustained phases of the respective hormone-releasing profiles ( Table II). The first phase of insulin release due to $15 \mathrm{mM}$ amino acids is maximal at $3.75 \mathrm{mM}$ glucose, while the second phase continues to increase up to the highest glucose level used $(6.25 \mathrm{mM})$ (Fig. 5, Table II). The $\alpha$-cells are even more sensitive to the action of glucose; maximal inhibition of the first phase of the glucagon response is already reached at the lowest glucose levels tested $(1.25 \mathrm{mM})$. Glucose suppression of the second phase of glucagon secretion was, however, less effective, and inhibition was incremental over the entire range of glucose concentrations (Fig. 5, Tables II and III). The most dramatic change occurred when the glucose level was increased from 2.5 to $3.75 \mathrm{mM}$.

These data might indicate that in the absence of stimulated insulin release, glucagon and insulin release during the first phase are unrelated, but do not preclude an interdependence in the secretion of the two hormones during the second phase, when the rates of insulin release are high (Fig. 6). These results imply that the glucose effect on $\alpha$-cells may at least in part be independent of the insulin-releasing capacity. It is, however, not possible with the present information to determine whether the low base-line levels of insulin might not suffice to facilitate glucose entry into the $\alpha$-cell, leading to inhibition.

It is noteworthy that in the prestimulatory phase, without amino acids in the perfusate, significant suppression of glucagon secretion occurs only at 5-6.25 mM concentrations ( $P<0.01$ for both) (Table III). In the poststimulatory phase, except for the first minute after removal of the amino acid stimulus, secretion rates were lower than in the prestimulatory phase and no further inhibition of glucagon release was apparent with increasing glucose concentrations (Table III).

\section{DISCUSSION}

Two aspects of the present results deserve detailed comment; $(a)$ the physiological role of glucose as primary modulator of $\alpha$ - and $\beta$-cell function, and $(b)$ the molecular mechanisms possibly underlying the multiple actions of glucose on islet cells.

Physiologic modulation of $\alpha$ - and $\beta$-cell function by glucose. The picture of physiological $\alpha$ - and $\beta$-cell function evolving from the present study and from the data in the literature may be sketched as follows: in the absence of external stimuli, which would include circulating substrates and possibly stimulatory inputs from the autonomic nervous system (18) and other unknown humoral factors, both $\alpha$-cells as well as $\beta$-cells are in a state of rest, exhibiting low basal rates of hormone release only a few percent of their secretion potential. The data are incompatible with the view that

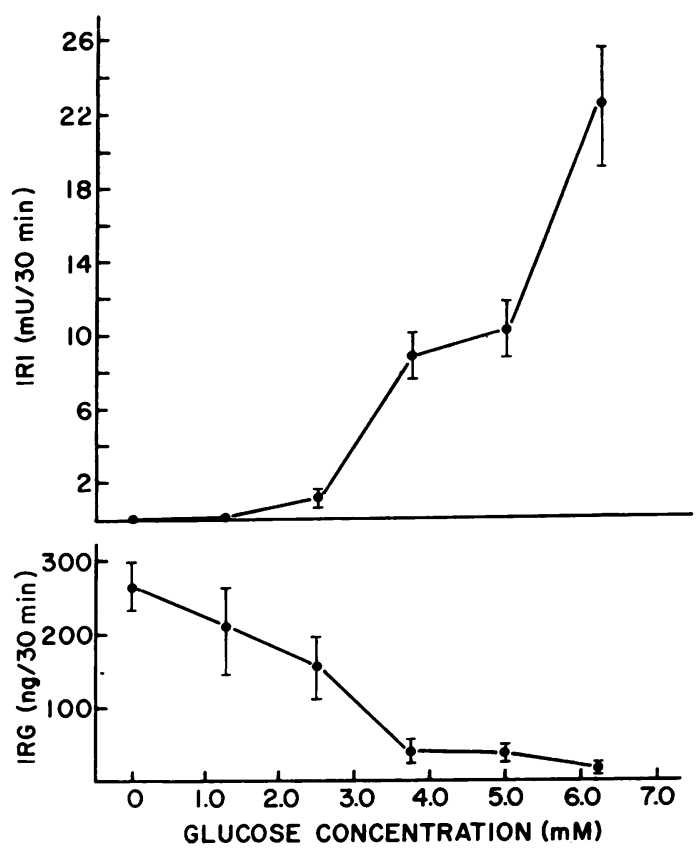

FIGURE 5 Dose-dependency of the modulator action of glucose on insulin and glucagon release due to $15 \mathrm{mM}$ amino acid mixture. Total hormone release during $30 \mathrm{~min}$ of exposure to the amino acid mixture is recorded as a function of the glucose concentration in the perfusion medium. Each value represents the mean $\pm S E M$ of three perfusion experiments and was obtained by planimetry of the area under the releasing profiles at each glucose concentration. Correction for basal release was made as described in the legend to Fig. 4, except in the case of insulin with the 6.25 $\mathrm{mM}$ glucose level, in which condition the base line was obtained experimentally by perfusing the pancreas for 75 min with $6.25 \mathrm{mM}$ glucose in the absence of the amino acid mixture (see Table II).

$\alpha$-cells have substantial spontaneous activity when deprived of glucose (1). If the latter hypothesis were correct, one could expect aglycemic perfusion of the pancreas to result in a marked elevation of glucagon release. The consistent decrease in basal glucagon release with 5 and $6.25 \mathrm{mM}$ glucose (Fig. 1, Table III), comparable to that observed in the perfused canine pancreas (6), would appear to be relatively unimportant by itself and may merely be indicative of the operative principle of glucose suppression of $\alpha$-cell function. It would appear that $\alpha$-cells, like the $\beta$-cells, are equally maintained in a state of rest provided external stimuli are absent.

The slow resting rate of hormone release, which amounts to only a few percent of the rate observed during physiological stimulation, is not necessarily artifactual, i.e. an indication of cell damage as a result of unfavorable extracorporeal conditions. Slow basal hormone release might well be analogous to the spontaneous physiological release of acetylcholine packets from 
TABLE III

Dose-Dependency of Glucose Inhibition of

\begin{tabular}{|c|c|c|c|c|c|c|c|c|c|c|c|c|c|c|}
\hline \multirow{3}{*}{$\begin{array}{l}\text { Sampling } \\
\text { time, min } \\
\text { glucose in } \\
\text { perfusate }\end{array}$} & \multirow{2}{*}{\multicolumn{4}{|c|}{ Prestimulatory phase }} & \multicolumn{10}{|c|}{ Stimulatory phase, amino acid mixture $(15 \mathrm{mM})$} \\
\hline & & & & & \multicolumn{5}{|c|}{ 1st phase } & \multicolumn{5}{|c|}{ 2nd phase } \\
\hline & -5 & -2 & 0 & $\begin{array}{c}\text { Mean } \\
\pm \text { SEM }\end{array}$ & 0.5 & 1 & 2 & 3 & $\begin{array}{l}\text { Mean } \\
\pm \text { SEM }\end{array}$ & 4 & 5 & 10 & 15 & 20 \\
\hline \multicolumn{15}{|l|}{$m M$} \\
\hline 0 & $\begin{array}{r}0.73 \\
\pm 0.17\end{array}$ & $\begin{array}{r}0.72 \\
\pm 0.19\end{array}$ & $\begin{array}{r}0.85 \\
\pm 0.17\end{array}$ & $\begin{array}{r}0.77 \\
\pm 0.04\end{array}$ & $\begin{array}{r}21.73 \\
\pm 2.20\end{array}$ & $\begin{array}{r}8.30 \\
\pm 0.56\end{array}$ & $\begin{array}{r}1.34 \\
\pm 0.19\end{array}$ & $\begin{array}{r}0.95 \\
\pm 0.16\end{array}$ & $\begin{array}{r}8.11 \\
\pm 2.60\end{array}$ & $\begin{array}{r}1.26 \\
\pm 0.42\end{array}$ & $\begin{array}{r}1.94 \\
\pm 0.55\end{array}$ & $\begin{array}{r}7.48 \\
\pm 1.56\end{array}$ & $\begin{array}{r}11.87 \\
\pm 0.64\end{array}$ & $\begin{array}{r}13.53 \\
\pm 1.63\end{array}$ \\
\hline 1.25 & $\begin{array}{r}0.80 \\
\pm 0.07\end{array}$ & $\begin{array}{r}0.76 \\
+0.09\end{array}$ & $\begin{array}{r}0.81 \\
\pm 0.06\end{array}$ & $\begin{array}{r}0.79 \\
\pm 0.02\end{array}$ & $\begin{array}{r}12.75 \\
\pm 0.56\end{array}$ & $\begin{array}{r}2.39 \\
\pm 0.38\end{array}$ & $\begin{array}{r}0.58 \\
\pm 0.16\end{array}$ & $\begin{array}{r}0.72 \\
\pm 0.25\end{array}$ & $\begin{array}{r}4.11 \ddagger \\
\pm 1.31\end{array}$ & $\begin{array}{r}0.66 \\
\pm 0.32\end{array}$ & $\begin{array}{r}1.58 \\
\pm 0.74\end{array}$ & $\begin{array}{r}7.11 \\
\pm 3.16\end{array}$ & $\begin{array}{r}9.74 \\
\pm 2.56\end{array}$ & $\begin{array}{r}10.60 \\
\pm 2.00\end{array}$ \\
\hline 2.50 & $\begin{array}{r}0.66 \\
\pm 0.04\end{array}$ & $\begin{array}{r}0.68 \\
\pm 0.06\end{array}$ & $\begin{array}{r}0.75 \\
\pm 0.14\end{array}$ & $\begin{array}{r}0.70 \\
\pm 0.03\end{array}$ & $\begin{array}{r}8.95 \\
\pm 0.42\end{array}$ & $\begin{array}{r}1.56 \\
\pm 0.20\end{array}$ & $\begin{array}{r}0.45 \\
\pm 0.04\end{array}$ & $\begin{array}{r}0.55 \\
\pm 0.06\end{array}$ & $\begin{array}{r}2.88 \ddagger \\
\pm 1.07\end{array}$ & $\begin{array}{r}0.50 \\
\pm 0.78\end{array}$ & $\begin{array}{r}0.86 \\
\pm 0.32\end{array}$ & $\begin{array}{r}3.21 \\
\pm 1.42\end{array}$ & $\begin{array}{r}7.60 \\
\pm 2.48\end{array}$ & $\begin{array}{r}8.65 \\
\pm 2.18\end{array}$ \\
\hline 3.75 & $\begin{array}{r}0.72 \\
\pm 0.07\end{array}$ & $\begin{array}{r}0.76 \\
\pm 0.08\end{array}$ & $\begin{array}{r}0.81 \\
\pm 0.02\end{array}$ & $\begin{array}{r}0.76 \\
\pm 0.03\end{array}$ & $\begin{array}{r}8.88 \\
\pm 0.51\end{array}$ & $\begin{array}{r}2.24 \\
\pm 0.16\end{array}$ & $\begin{array}{r}0.63 \\
\pm 0.01\end{array}$ & $\begin{array}{r}0.42 \\
\pm 0.04\end{array}$ & $\begin{array}{r}3.04 \ddagger \\
\pm 1.04\end{array}$ & $\begin{array}{r}0.48 \\
\pm 0.01\end{array}$ & $\begin{array}{r}0.56 \\
\pm 0.05\end{array}$ & $\begin{array}{r}1.35 \\
\pm 0.31\end{array}$ & $\begin{array}{r}2.11 \\
\pm 0.78\end{array}$ & $\begin{array}{r}2.61 \\
\pm 1.04\end{array}$ \\
\hline 5.00 & $\begin{array}{r}0.55 \\
\pm 0.04\end{array}$ & $\begin{array}{r}0.44 \\
\pm 0.11\end{array}$ & $\begin{array}{r}0.39 \\
\pm 0.07\end{array}$ & $\begin{array}{c}0.46 \ddagger \\
\pm 0.05\end{array}$ & $\begin{array}{r}11.27 \\
\pm 1.85\end{array}$ & $\begin{array}{r}1.38 \\
\pm 0.42\end{array}$ & $\begin{array}{r}0.61 \\
\pm 0.53\end{array}$ & $\begin{array}{r}0.41 \\
\pm 0.17\end{array}$ & $\begin{array}{r}3.67 \ddagger \\
\pm 1.50\end{array}$ & $\begin{array}{r}0.45 \\
\pm 0.02\end{array}$ & $\begin{array}{r}0.57 \\
\pm 0.11\end{array}$ & $\begin{array}{r}1.04 \\
\pm 0.23\end{array}$ & $\begin{array}{r}2.10 \\
\pm 0.46\end{array}$ & $\begin{array}{r}1.64 \\
\pm 0.82\end{array}$ \\
\hline 6.25 & $\begin{array}{r}0.35 \\
\pm 0.06\end{array}$ & $\begin{array}{r}0.25 \\
\pm 0.07\end{array}$ & $\begin{array}{r}0.30 \\
\pm 0.06\end{array}$ & $\begin{array}{l}0.30 \ddagger \\
\pm 0.03\end{array}$ & $\begin{array}{r}6.67 \\
\pm 1.40\end{array}$ & $\begin{array}{r}0.96 \\
\pm 0.08\end{array}$ & $\begin{array}{r}0.48 \\
\pm 0.05\end{array}$ & $\begin{array}{r}0.42 \\
\pm 0.05\end{array}$ & $\begin{array}{l}2.13 \ddagger \\
\pm 0.66\end{array}$ & $\begin{array}{r}0.42 \\
\pm 0.03\end{array}$ & $\begin{array}{r}0.50 \\
\pm 0.08\end{array}$ & $\begin{array}{r}0.64 \\
\pm 0.11\end{array}$ & $\begin{array}{r}0.80 \\
\pm 0.12\end{array}$ & $\begin{array}{r}0.90 \\
\pm 0.18\end{array}$ \\
\hline
\end{tabular}

* The results presented in this table are from the experiments described in Fig. 5. Glucagon values are recorded in nanograms per minute.

$\ddagger P \leq 0.01$ by Student $t$ test when compared to aglycemic perfusion.

$\S$ Mean \pm SEM of poststimulatory phase was calculated by omitting the transitional 30.5 and 31 -min values.

the nerve terminal in the absence of a nerve impulse, as manifested by miniature end plate potentials (20).

In the absence of glucose, $\alpha$-cells are sensitized, able to respond readily to physiological levels of amino acids, whereas the $\beta$-cells are unresponsive to this major group of fuel molecules. This nonresponsiveness of the $\beta$-cells devoid of glucose extends to almost all physiologic stimuli, studied so far, including fatty acids, ketone bodies, secretin, pancreozymin, glucagon, and certain metabolites of amino acids. Glucose profoundly alters the chemosensitivity of both kinds of cell, but oppositely. Secretion of glucagon, induced by amino acids or by enteric hormones (6), is partially inhibited by physiologically low glucose levels $(1-2 \mathrm{mM})$, and is almost entirely blocked by normal sugar levels $(5-6 \mathrm{mM})$.

Glucose sensitizes the $\beta$-cells to secretory stimuli, in contrast to its action on $\alpha$-cells. It was shown here with amino acids and in a parallel study with DL- $B$-hydroxybutyrate that there is a threshold close to $2.5 \mathrm{mM}$ for the permissive action of glucose that allows other molecules to release insulin, and that the glucose effect increases dramatically at levels exceeding this threshold. This should be physiologically advantageous. It would make little sense if the $\beta$-cells responded with insulin output to other molecules if the blood sugar were dangerously low, i.e., $2.5 \mathrm{mM}$ or less. Glucose can therefore be considered as a safety switch, turning off the $\beta$-cells during hypoglycemia and sensitizing them when the blood sugar is normal or higher. As the blood sugar

\footnotetext{
- Manuscript in preparation.
}

falls, $\alpha$-cells become deinhibited and the stimulatory factors gain increasing influence, thus curbing hypoglycemia. Similar ideas concerning the modulating role of glucose in $\beta$-cell responsiveness were derived from in vivo studies in man, using arginine, tolbutamide, and glucagon as secretagogues $(21,22)$.

What is the physiological significance of the biphasic glucagon response to amino acid stimulation? Since the temporal profile of amino acid-induced glucagon release resembles that of insulin release due to high glucose or amino acids plus basal glucose, one cannot help asking whether the biphasic glucagon release pattern might have similar significance as attributed to the biphasic insulin secretion pattern, and whether the widely accepted two-compartment model of insulin release applies to glucagon secretion from the $\alpha$-cells as well. It is difficult to describe physiologic conditions that might cause substrate-induced biphasic glucagon release due to rapid rises in amino acids in blood, in contrast to the frequently encountered dramatic changes of the blood sugar levels. The vampire bat is probably one of the few mammals exhibiting large and rapid fluctuations in serum amino acids, which occur after a blood meal. ${ }^{5}$ However, the possibility that neuronal and enterohormonal factors might modulate $\alpha$-cell function in ways that demand the capacity for an abrupt, biphasic response must be considered in most other species.

With the information currently available, it is impossible to explain the mechanism of the biphasic response

\footnotetext{
${ }^{5}$ George Cahill, Jr. Personal communication.
} 


\begin{tabular}{|c|c|c|c|c|c|c|c|c|c|c|c|c|c|c|}
\hline \multirow[b]{2}{*}{25} & \multirow[b]{2}{*}{.30} & \multirow[b]{2}{*}{$\begin{array}{c}\text { Mean } \\
\pm \text { SEM }\end{array}$} & \multicolumn{12}{|c|}{ Post-stimulatory phase } \\
\hline & & & 30.5 & 31 & 32 & 33 & 34 & .35 & 40 & 45 & 50 & 55 & 60 & $\begin{array}{l}\text { Means } \\
\pm \mathrm{SEM}\end{array}$ \\
\hline $\begin{array}{r}1.3 .00 \\
\pm 1.51\end{array}$ & $\begin{array}{r}12.33 \\
\pm 0.78\end{array}$ & $\begin{array}{r}8.77 \\
\pm 1.17\end{array}$ & $\begin{array}{r}3.54 \\
\pm 0.33\end{array}$ & $\begin{array}{r}1.83 \\
\pm 0.24\end{array}$ & $\begin{array}{r}0.70 \\
\pm 0.10\end{array}$ & $\begin{array}{r}0.48 \\
\pm 0.11\end{array}$ & $\begin{array}{r}0.29 \\
\pm 0.15\end{array}$ & $\begin{array}{r}0.16 \\
\pm 0.16\end{array}$ & $\begin{array}{r}0.32 \\
\pm 0.17\end{array}$ & $\begin{array}{r}0.20 \\
\pm 0.20\end{array}$ & $\begin{array}{r}0.13 \\
\pm 0.13\end{array}$ & $\begin{array}{r}0.15 \\
\pm 0.15\end{array}$ & $\begin{array}{r}0.20 \\
\pm 0.12\end{array}$ & $\begin{array}{r}0.29 \\
\pm 0.06\end{array}$ \\
\hline $\begin{array}{r}10.43 \\
\pm 1.86\end{array}$ & $\begin{array}{r}11.55 \\
\pm 1.60\end{array}$ & $\begin{array}{r}7.38 \\
\pm 1.04\end{array}$ & $\begin{array}{r}1.73 \\
\pm 0.53\end{array}$ & $\begin{array}{r}0.75 \\
\pm 0.11\end{array}$ & $\begin{array}{r}0.23 \\
\pm 0.12\end{array}$ & $\begin{array}{r}0.18 \\
\pm 0.07\end{array}$ & $\begin{array}{r}0.14 \\
\pm 0.05\end{array}$ & $\begin{array}{r}0.12 \\
\pm 0.05\end{array}$ & $\begin{array}{r}0.12 \\
\pm 0.04\end{array}$ & $\begin{array}{r}0.18 \\
\pm 0.03\end{array}$ & $\begin{array}{r}0.20 \\
\pm 0.08\end{array}$ & $\begin{array}{r}0.15 \\
\pm 0.02\end{array}$ & $\begin{array}{r}0.21 \\
\pm 0.01\end{array}$ & $\begin{array}{r}0.17 \\
\pm 0.01\end{array}$ \\
\hline $\begin{array}{r}9.10 \\
\pm 1.54\end{array}$ & $\begin{array}{r}9.30 \\
\pm 1.40\end{array}$ & $\begin{aligned} & 5.60_{+}^{+} \\
\pm & 0.96\end{aligned}$ & $\begin{array}{r}1.55 \\
\pm 0.42\end{array}$ & $\begin{array}{r}0.50 \\
\pm 0.06\end{array}$ & $\begin{array}{r}0.34 \\
\pm 0.08\end{array}$ & $\begin{array}{r}0.29 \\
\pm 0.05\end{array}$ & $\begin{array}{r}0.25 \\
\pm 0.04\end{array}$ & $\begin{array}{r}0.20 \\
\pm 0.04\end{array}$ & $\begin{array}{r}0.27 \\
\pm 0.04\end{array}$ & $\begin{array}{l}0.24 \\
0.26\end{array}$ & $\begin{array}{r}0.26 \\
\pm 0.07\end{array}$ & $\begin{array}{r}0.25 \\
\pm 0.06\end{array}$ & $\begin{array}{r}0.26 \\
\pm 0.06\end{array}$ & $\begin{array}{r}0.26 \\
\pm 0.01\end{array}$ \\
\hline $\begin{array}{r}3.18 \\
\pm 0.99\end{array}$ & $\begin{array}{r}2.98 \\
\pm 0.83\end{array}$ & $\begin{array}{r}1.89 \ddagger \\
\pm 0.32\end{array}$ & $\begin{array}{r}0.82 \\
\pm 0.18\end{array}$ & $\begin{array}{r}0.49 \\
\pm 0.12\end{array}$ & $\begin{array}{r}0.32 \\
\pm 0.02\end{array}$ & $\begin{array}{r}0.27 \\
\pm 0.01\end{array}$ & $\begin{array}{r}0.32 \\
\pm 0.05\end{array}$ & $\begin{array}{r}0.27 \\
\pm 0.03\end{array}$ & $\begin{array}{r}0.26 \\
\pm 0.04\end{array}$ & $\begin{array}{r}0.25 \\
\pm 0.02\end{array}$ & $\begin{array}{r}0.10 \\
\pm 0.04\end{array}$ & $\begin{array}{r}0.12 \\
\pm 0.0 .3\end{array}$ & $\begin{array}{r}0.15 \\
\pm 0.03\end{array}$ & $\begin{array}{r}0.23 \\
\pm \mathrm{C} .06\end{array}$ \\
\hline $\begin{array}{r}2.21 \\
\pm 0.79\end{array}$ & $\begin{array}{r}1.97 \\
\pm 0.93\end{array}$ & $\begin{array}{l}1.42 \ddagger \\
\pm 0.24\end{array}$ & $\begin{array}{r}0.67 \\
\pm 0.04\end{array}$ & $\begin{array}{r}0.58 \\
\pm 0.04\end{array}$ & $\begin{array}{r}0.22 \\
\pm 0.02\end{array}$ & $\begin{array}{r}0.26 \\
\pm 0.02\end{array}$ & $\begin{array}{r}0.27 \\
\pm 0.03\end{array}$ & $\begin{array}{r}0.27 \\
\pm 0.04\end{array}$ & $\begin{array}{r}0.37 \\
\pm 0.13\end{array}$ & $\begin{array}{r}0.20 \\
\pm 0.06\end{array}$ & $\begin{array}{r}0.23 \\
\pm 0.07\end{array}$ & $\begin{array}{r}0.19 \\
\pm 0.03\end{array}$ & $\begin{array}{r}0.21 \\
\pm 0.04\end{array}$ & $\begin{array}{r}0.25 \\
\pm 0.05\end{array}$ \\
\hline $\begin{array}{r}0.9 .3 \\
\pm 0.17\end{array}$ & $\begin{array}{r}0.98 \\
\pm 0.15\end{array}$ & $\begin{aligned} & 0.74 \ddagger \\
\pm & 0.06\end{aligned}$ & $\begin{array}{r}0.39 \\
\pm 0.05\end{array}$ & $\begin{array}{r}0.41 \\
\pm 0.06\end{array}$ & $\begin{array}{r}0.33 \\
\pm 0.06\end{array}$ & $\begin{array}{r}0.26 \\
\pm 0.05\end{array}$ & $\begin{array}{r}0.26 \\
\pm 0.05\end{array}$ & $\begin{array}{r}0.23 \\
\pm 0.07\end{array}$ & $\begin{array}{r}0.25 \\
\pm 0.06\end{array}$ & $\begin{array}{r}0.28 \\
\pm 0.06\end{array}$ & $\begin{array}{r}0.22 \\
\pm 0.08\end{array}$ & $\begin{array}{r}0.25 \\
\pm 0.07\end{array}$ & $\begin{array}{r}0.24 \\
\pm 0.04\end{array}$ & $\begin{array}{r}0.26 \\
\pm 0.01\end{array}$ \\
\hline
\end{tabular}

of the $\alpha$-cells. Like biphasic insulin release by the $\beta$-cells, an equally unsettled issue, multiphasic glucagon release might be due to multiple pools of the hormone, feedback control by the released glucagon itself or by unknown intracellular regulators (i.e. cyclic nucleotides, ions, or metabolites), or possibly even various combinations of the above mechanisms.

It remains also to be seen whether there are pathologic states, analogous to the adult-onset form of diabetes where the first phase of insulin release is blunted, in which the first phase of glucagon release is similarly affected.

The molecular mechanisms of the multiple actions of glucose in islet colls. How does the glucose molecule accomplish these multiple effects on $\alpha$ - and $\beta$-cells? First, on must answer the question of whether the effects of glucose on $\alpha$ - and $\beta$-cells are direct or indirect. Samols, Tyler, and Marks (23) propose that glucose suppression of glucagon secretion is a consequence of elevated insulin levels at the $\alpha$-cells, and they also imply that amino acid-induced insulin release depends conversely upon elevated glucagon concentrations at the $\beta$-cells. At first glance, the data in this paper and in the literature $(1,2,5-7,23)$ seem to be compatible with this view. However, a closer look at the results of the present study reveals that the rates of glucagon and insulin release are not always inversely related, as one would expect if this concept were correct. In particular, low glucose levels inhibit the first phase of amino acidinduced glucagon release without augmenting basal in- sulin release. More convincingly, it was found in a parallel study with pancreases of both alloxan- and streptozotocin-diabetic rats that glucose suppression of $\alpha$-cell function is independent of insulin (24).

From the present data, it seems unlikely that amino acid-induced insulin release is in any way dependent upon concomitant glucagon secretion, since insulin secretion is maximal when glucagon release is low or almost ceases. Furthermore, there are physiological stimulants with no effect on glucagon release but with powerful insulin-releasing action (e.g. $\beta$-hydroxybutyrate ${ }^{4}$ ).

Assuming then, in contrast to most current beliefs, that glucose acts directly on $\alpha$ - as well as on $\beta$-cells, one has to consider a priori the following possible mechanisms for its action. (The mechanism could be the same in each type of cell except for an opposite sign.) They are: $(a)$ transport of glucose into the cell; $(b)$ phosphorylation of glucose; $(c)$ further metabolism of glucose by the cell; $(d)$ interaction of glucose with a receptor on the external surface of the cell; and $(e)$ various combinations of the above.

Extensive studies have been performed to differentiate which of the above molecular mechanisms might be the basis of the permissive action of glucose on the $\beta$-cells $(11,17,25-29)$, whereas analogous studies of the glucose modulation of $\alpha$-cell function are scanty $(2,30)$. This disproportionate availability of knowledge on the two types of cells is because in rat and mouse, the two species preferentially studied, the contribution of $\alpha$-cells to the islet tissue mass is only $15-30 \%$, compared to 

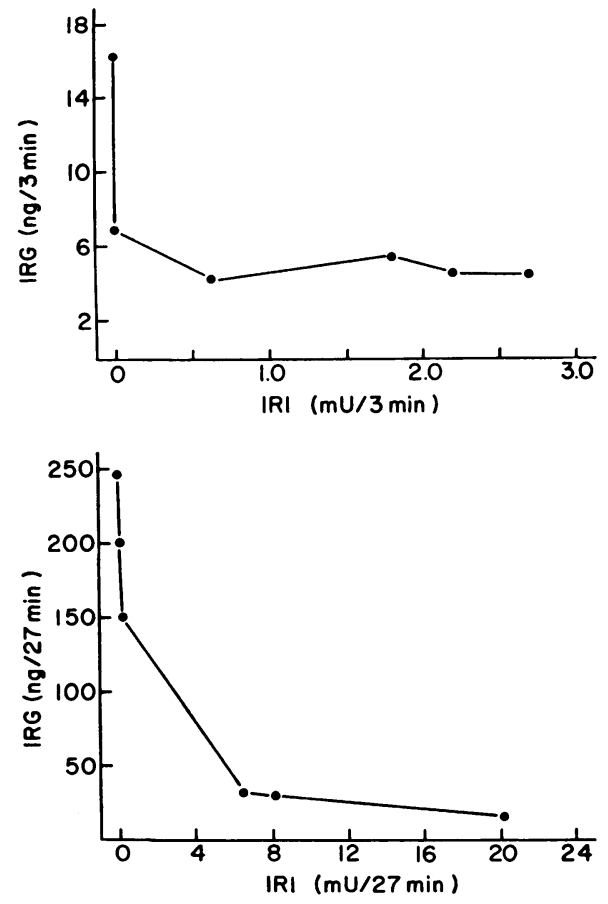

Figure 6 Relationship between insulin and glucagon in the first phase and the second phase of release above basal secretion rates caused by $15 \mathrm{mM}$ amino acid mixture and increasing concentrations of glucose (see Table II).

$75-60 \%$ in the case of the $\beta$-cells, (the remaining $10 \%$ is contributed by stroma $[31,32])$. Therefore, the available data have usually been interpreted as being representative for the $\beta$-cells. Although this is debatable, we will follow this approach in the following discussion.

Carrier-mediated transport across the cell membrane, as shown to exist in islets, is probably not the critical glucose-sensitive step of $\beta$-cells, because fructose, which is unable to stimulate insulin release in the rat, penetrates as rapidly as glucose, presumably via the same carrier system (11). Further, mannoheptulose blocks insulin release by glucose without interfering with glucose penetration (25).

If phosphorylation of glucose were the essential event, one would expect that both fructose and 2-deoxyglucose would function as triggers for insulin release, whereas sorbitol and xylitol, sugar alcohols that are not phosphorylated, should not; however, just the opposite is the case (11).

The argument in favor of the third, more popular alternative, that of a mechanism dependent on further glucose metabolism, is also not convincing. The most compelling evidence against the general metabolism hypothesis is the recent demonstration with isolated perifused islets that releasing and fuel function of glucose can be completely dissociated with iodoacetate (26). It is pertinent in this context that neither $5 \mathrm{mM}$ mannose nor $20 \mathrm{mM}$ fructose, which are suitable fuels for the islets, can substitute for glucose in its capacity to sensitize the $\beta$-cells to stimulation by isoleucine (17). Other evidence that the permissive action of glucose is almost certainly not due to provision of energy is derived from studies with the isolated perfused pancreas, in which it was found that ATP and $P$-creatine levels of islet tissue were the same in the absence and presence of glucose (11). The observations that metabolite profiles within the islets change only very sluggishly or not at all with glucose and are not correlated with insulin release give further indirect support for an alternate hypothesis explaining glucose-dependent insulin secretion (11).

Despite the lack of corresponding knowledge concerning the biochemistry of $\alpha$-cell metabolism, we feel it is fruitful to outline a general working hypothesis for further studies. This hypothesis invokes glucoreceptors and amino acid receptors common to both the $\alpha$ - and $\beta$-cell (Fig. 7). In the case of the $\beta$-cell, occupation of amino acid receptor sites does not result in insulin release unless at least some of the glucoreceptors are also occupied. Occupation of a high proportion of the glucoreceptors can cause release in the absence of amino acids, but not vice versa. In contrast, in the case of the $\alpha$-cell, occupation of amino acid receptors alone can cause glucagon release, whereas occupancy of glucoreceptors results in a conformational change in the amino acid receptors that blocks glucagon release. In this

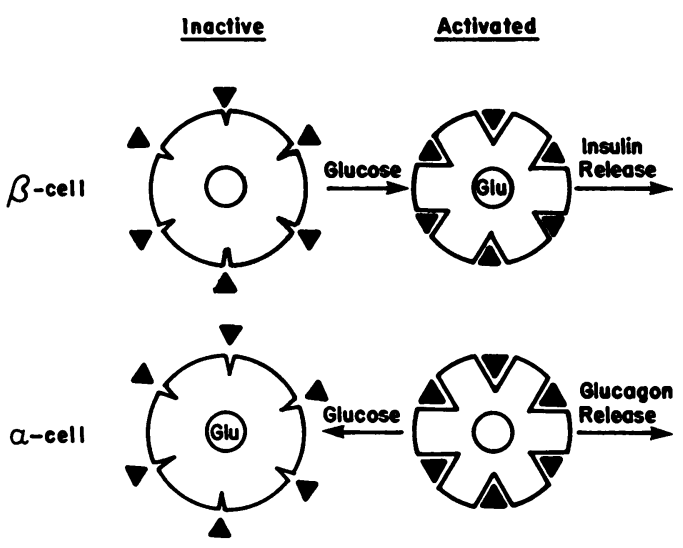

FIGURE 7 Activation and inhibition of amino acid receptors by glucose in $\beta$-cells and $\alpha$-cells, respectively. Amino acid sites are depicted arbitrarily by a set of notches, amino acids by triagonal shapes, and the glucose site by a central circle. The glucose molecule is represented by the abbreviation GLU. In the $\beta$-cells, addition of glucose makes the amino acid sites accessible to the agonists, whereas in the $\alpha$-cells, addition of glucose drastically decreases affinity of the agonists to their receptor sites. The "activated" receptor leads to hormone release. 
model the intensity of release of each hormone is dependent upon the relative concentrations of both glucose and amino acids. This hypothesis is simple, compatible with our data and the data in the literature, and is open for further rigorous testing.

\section{ACKNOWLEDGMENTS}

We would like to thank Mrs. Joy Brothers and Mrs. Veronica Frazier for their technical assistance and Mrs. Karen Lambarth for typing the manuscript.

Dr. Matschinsky is a recipient of a Research Career Development Award GM 42374. This work was supported by U. S. Public Health Service research grants AM 10591 and $\mathrm{AM} 06355$.

\section{REFERENCES}

1. Unger, R. H., and P. J. Lefebvre. 1972. Glucagon physiology. In Glucagon. P. J. Lefebvre and R. H. Unger, editors. Pergamon Press Ltd., New York. 1st edition. 213-244.

2. Edwards, J. C., and K. W. Taylor. 1970. Fatty acids and the release of glucagon from isolated guinea pig islets of Langerhans incubated in vitro. Biochem Biophys. Acta. 215: 310-315.

3. Luyckx, A. S., and P. J. Lefebvre. 1970. Arguments for a regulation of pancreatic glucagon secretion by circulating plasma free fatty acids. Proc. Soc. Exp. Biol. Med. 133 : 524-528.

4. Madison, L. L., D. Mebane, R. H. Unger, and A. Lochner. 1964. The hypoglycemic action of ketones. II. Evidence for a stimulatory feedback of ketones on pancreatic $\beta$-cells. J. Clin. Invest. 43: 408-415.

5. Muller, W. A., G. R. Faloona, E. Aquilar-Parada, and R. H. Unger. 1970. Abnormal alpha cell function in diabetes: response to carbohydrate and protein. N. Engl. J. Med. 283 : 109-115.

6. Iversen, J. 1971. Secretion of glucagon and insulin from the isolated, perfused canine pancreas. J. Clin. Invest. 50: 2123-2136.

7. Rocha, D. M., G. R. Faloona, and R. H. Unger. 1972. Glucagon-stimulating activity of 20 amino acids in dogs. J. Clin. Invcst. 51 : 2346-2351.

8. Muller, W. A., G. R. Faloona, and R. H. Unger. 1971. Effect of experimental insulin deficiency on glucagon secretion. J. Clin. Invest. 50: 1992-1999.

9. Grodsky, G. M., A. A. Bates, L. L. Bennett, C. Vcella, N. B. McWilliams, and D. F. Smith. 1963. Effects of carbohydrates on secretion of insulin from isolated rat pancreas. Am. J. Physiol. 205: 638-644.

10. Landgraf, R., J. Kotler-Brajtburg, and F. M. Matschinsky. 1971. Kinetics of insulin release from the perfused rat pancreas caused by glucose, glucosamine and galactose. Proc. Natl. Acad. Sci. U. S. A. 68: 536-540.

11. Matschinsky, F. M., R. Landgraf, J. Ellerman, and J. Kotler-Brajtburg. 1972. Glucoreceptor mechanisms in islets of Langerhans. Diabetes. 21: (Suppl. 2) 555-569.

12. Grodsky, G. M. 1971. A threshold distribution hypothesis for packet storage of insulin. II. Effect of calcium. Diabctcs. 21 : (Suppl. 2) 584-593.
13. Scharff, R., and I. G. Wool. 1964. Concentration of amino acids in rat muscle and plasma. Nature (Lond.). 202: 603-604.

14. Hales, C. N., and P. J. Randle. 1963. Immunoassay of insulin with insulin-antibody precipitate. Biochem. J. 88: $137-146$.

15. Hunter, W. M., and F. C. Greenwood. 1962. Preparation of iodine-131 labelled human growth hormone of high specific activity. Nature (Lond.). 194: 495-496.

16. Levin, S. R., G. M. Grodsky, R. Hagura, D. F. Smith, and P. Forsham. 1972. Relationship between arginine and glucose in the induction of insulin secretion from isolated perfused rat pancreas. Endocrinology. 90: 624631.

17. Matschinsky, F. M., R. Fertel, J. Kotler-Brajtburg, S. Stillings, J. Ellerman, F. Raybaud, and J. HolowachThurston. 1973. Factors governing the action of small calorigenic molecules on the islets of Langerhans. Proceedings of the 8th Midwest Conference of Endocrinology and Metabolism; R. P. Breitenbach and X. J. Mussachia, editors. Columbia, Mo., October 9-10, 1972, University of Missouri, Columbia, Mo. 63-86.

18. Marliss, E. B., L. Girardier, J. Seydoux, C. B. Wollheim, Y. Kanazawa, L. Orci, A. E. Renold, and D. Porte, Jr. 1973. Glucagon release induced by pancreatic nerve stimulation in the dog. J. Clin. Invest. 52: 12461259.

19. Fajans, S. S., J. C. Floyd, Jr., R. F. Knopf, and J. W. Conn. 1967. Effect of amino acids and proteins on insulin secretion in man. Recent Prog. Horm. Res. 23: $617-662$.

20. Woodbury, J. H., A. M. Gordon, and J. T. Conrad. 1965. Muscle. In Physiology and Biophysics. T. C. Ruch and H. D. Patton, editors. W. B. Saunders Company, Philadelphia. 113-152.

21. Efendic, S., E. Cerasi, and R. Luft. 1971. Role of glucose in arginine-induced insulin release in man. $M e$ tab. (Clin. Exp.). 20: 568-579.

22. Pagliara, A. S., I. E. Karl, D. C. De Vivo, R. D Feigin, and D. M. Kipnis. 1972. Hypoalaninemia: a concomitant of ketotic hypoglycemia. J. Clin. Invest. 51: 1440-1449.

23. Samols, E., J. M. Tyler, and V. Marks. 1972. Glucagon-insulin interrelationships. In Glucagon. P. J. Lefebvre and R. H. Unger, editors. Pergamon Press Inc., Elmsford, N. Y., 1st edition. 151-173.

24. Pagliara, A. S., S. N. Stillings, B. Hover, and F. M. Matschinsky. 1974. Insulin and glucose as modulators of the amino acid-induced glucagon release in the isolated perfused pancreas of the alloxan-diabetic rat. Clin. Res. 22: 476A.

25. Matschinsky, F. M., J. Ellerman, J. Krzanowski, J. Kotler-Brajtburg, R. Landgraf, and R. Fertel. 1971. The dual function of glucose in islets of Langerhans. J. Biol. Chem. 246: 1007-1011.

26. Matschinsky, F. M., and J. Ellerman. 1973. Dissociation of the insulin-releasing and the metabolic functions of hexoses in islets of Langerhans. Biochem. Biophys. Res. Commun. 50: 193-199.

27. Ashcroft, S. J. H., C. V. Hedescov, and P. J. Randle. 
1970. Glucose metabolism in mouse pancreatic islets. Biochcm. J. 118: 143-154.

28. Ashcroft, S. J. H., L. C. C. Weerasinghe, J. M. Bassett, and P. J. Randle. 1972. The pentose cycle and insulin release in mouse pancreatic islets. Biochem. $J$. 126: $525-532$.

29. Aleyassine, H. 1970. Energy requirements for insulin release from rat pancreas in vitro. Endocrinology. 87: 84-89.
30. Edwards, J. C. 1973. A-cell metabolism and glucagon secretion. Postgrad. Med. J. Suppl. 6: 611-615.

31. Lazarus, S. S., and B. W. Volk. 1962. The pancreas in human and experimental diabetes. Grune \& Stratton, Inc., New York. 25 pp.

32. Hoftiezer, V., and A. M. Carpenter. 1973. Comparison of streptozotocin and alloxan-induced diabetes in the rat, including volumetric quantitation of pancreatic islets. Diabetologica. 9 : 178-184. 